\title{
Failure properties of leaf valve inflatable saline breast implants
}

\author{
Walter Peters PhD MD FRCSC \\ Division of Plastic Surgery, Wellesley Central Hospital and the University of Toronto, Toronto, Ontario
}

\begin{abstract}
W Peters. Failure properties of leaf valve inflatable saline breast implants. Can J Plast Surg 1997;5(4):241-245. From 1992 to 1996, 189 saline breast implants were inserted into patients ( 54 for breast augmentation and 135 for replacement of explanted silicone gel implants). Nine implants (4.8\%) underwent spontaneous deflation at a mean of 2.8 months postoperation (range, 0.5 to nine months). Six deflations were partial ( $10 \%$ to $50 \%$ of implant volume), and three were complete. All failed implants were from the same manufacturer and had the same leaf valves. None of the failed implants demonstrated any visible defects in their walls or valve mechanisms when examined in the operating room. However, subsequent analyses indicated that all failed implants demonstrated a slow leak through the leaf valve mechanism - as slow as two to three drops per $12 \mathrm{~h}$. This rate increased significantly when pressure was applied to the implant. In the three implants with delayed leakage (six to 10 months), fibrous tissue was observed in the leaf valve mechanism of the implants. It is postulated that failure of all nine implants resulted because of defects in their valves and that fibrous tissue ingrowth into the leaf catheter valve mechanism may have played a role in at least three. The tissue may have provided a 'wick' to stimulate fluid leakage. The use of these leaf valve implants was discontinued one year ago. Since then, no failures have been observed in any of the 68 diaphragm valve implants that have been inserted during the past year.
\end{abstract}

Key Words: Failure, Saline breast implants

\section{Caractéristiques de l'échec de prothèses mammaires gonflables à solution saline avec soupape à lamelle}

RÉSUMÉ : Entre 1992 et 1996, 189 prothèses mammaires à solution saline ont été implantées chez des patientes (54 pour une augmentation mammaire et 135 pour remplacement de prothèse au gel de silicone). Neuf prothèses $(4,8 \%)$ se sont spontanément dégonflées en moyenne dans les 2,8 mois suivant l'opération (allant de 0,5 à 9 mois). Six dégonflements étaient partiels (de 10 à $50 \%$ du volume de la prothèse) et trois étaient complets. Toutes les prothèses défectueuses provenaient du même fabricant et comportaient la même soupape à lamelle. Aucune des prothèses défectueuses n'a présenté de signes visibles sur leur paroi ou dans le mécanisme de leurs soupape lors de leur examen au bloc opératoire. Toutefois, les analyses subséquentes ont indiqué que toutes les prothèses défectueuses présentaient une fuite par le mécanisme à lamelle, soit de 2 à 3 gouttes par 12 heures. Ce taux a augmenté significativement lorsqu'une pression était appliquée sur la prothèse. Dans les trois prothèses qui présentaient une fuite retard (6 à 10 mois), un tissu fibreux a été observé dans le mécanisme à lamelle des prothèses. On suppose que la défectuosité des prothèses a résulté d'anomalies de leur soupape et que la croissance du tissu fibreux dans le cathéter de la soupape peut avoir joué un rôle dans au moins trois de ces prothèses. Le tissu peut avoir stimulé la fuite de liquide. L'utilisation de ces prothèses a été cessée il y a un an. Depuis, on n'a noté aucune défectuosité des 68 prothèses à qui ont été installées au cours de l'année écoulée.

$\mathrm{I}_{\mathrm{c}}^{\mathrm{n}}$ n 1963, Cronin and Gerow (1) introduced the Silastic (silicone gel, Dow Corning, Tennessee) breast implant, opening the new era of breast augmentation surgery. This original 'Cronin' implant was made of a thick gel contained in a thick, rigid, elastomeric envelope, which had a Dacron (Dupont, Delaware) backing on the posterior surface to anchor the implant to the chest wall to attempt to reduce ptosis. It was available in only a limited number of sizes. Many women

Correspondence: Dr Walter Peters, Suite 418, 160 Wellesley Street East, Toronto, Ontario M4Y 1J3. Telephone 416-926-7790,

fax 416-926-4997, e-mail walter.peters@utoronto.ca who received these implants developed early and severe capsular contracture $(1,2)$.

Inflatable saline breast implants were introduced in 1965 by Dr Arion (the Simaplast implant [Toulons, France]) (3). The elastomeric envelopes were filled with a hypertonic solution (6\% dextran) or saline. Clinically, these implants were softer than the Cronin implant and were soon declared the first implant to produce a 'bouncy breast' (3). These implants could be inserted through a smaller incision than the gel implant and could be inflated to varying sizes, allowing a wider range of final breast sizes. Many manufacturers developed and marketed their own particular brand of inflatable implants (eg, Roger Klein Association [New York], Heyer- 

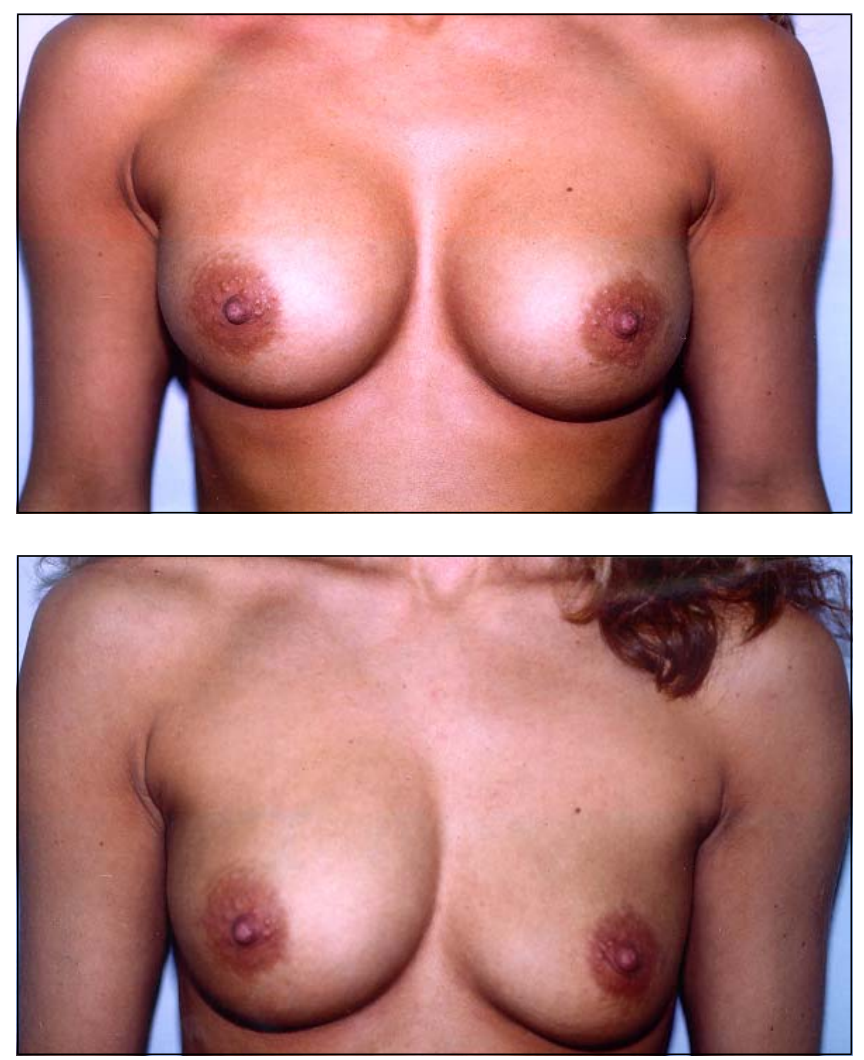

Figure 1) Top Patient two months after implantation (the upper pole of the left breast is already smaller than that of the right breast). Bottom Ten months after implantation, with total deflation of the left implant (Implant 9, Table 1)

Schulte [California], Dow Corning and Varifil [Michigan]). In Canada, from 1970 to 1971, Regnault and colleagues (4) helped develop and test an inflatable implant for Dow Corning; however, the early deflation rate of $8 \%$ during the first year forced them to discontinue the project.

By 1973 , spontaneous deflation rates of $76 \%$ to $88 \%$ over three years were reported with several types of saline implants $(5,6)$. Leaks were noted in seams, valve stems and valve mechanisms. Many of these implants were, therefore, removed from the market. Heyer-Schulte subsequently became the dominant player in the inflatable implant market. They introduced the hydrocephalic valve (developed by $\mathrm{Mr}$ Schulte), which decreased the deflation rate significantly (6). In addition, Heyer-Schulte changed the formulation of the elastomeric shell (5). Until then, most saline implants had clear, platinum-cured shells. Heyer-Schulte showed that the thicker, opaque, room temperature-vulcanized shells (the 'Jenny' prostheses) were less prone to failure than the platinum-cured shells, which were discontinued in 1976. By 1978 , the incidence of early deflation was reported to be only about $2 \%$ (8). In 1980, Heyer-Schulte published a $1.2 \%$ early deflation rate for their opaque implants (5). However, this figure was based on user-reported failures. While it was assumed that all failures were reported back to the manufacturer, there was no guarantee that this actually occurred. The largest period of follow-up in most of these reports was usu-
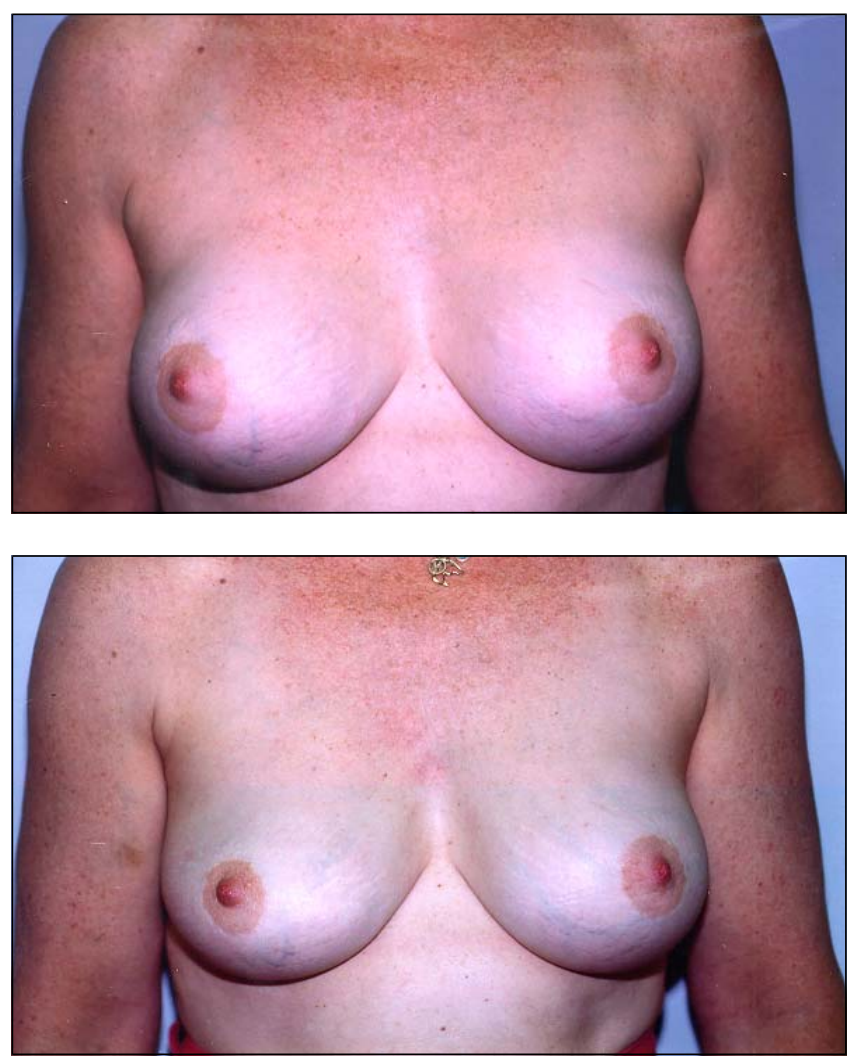

Figure 2) Top Patient two months after implantation. Bottom Patient six months after implantation with partial deflation of the right implant (Implant 8, Table 1)

ally only two to three years. These studies analyzed cases of early implant failure.

In 1980, Worton and co-workers (9) described a 'new' mechanism of failure in six patients with inflatable implants. This failure did not develop until six to seven years after insertion. In these patients, implants developed a small hole at the end of one of the wrinkles in the elastomeric shell. This was termed the 'fold flaw' leak and was thought to result from an 'internal abrasion' at a wrinkled (and presumably weakened) site in the shell. While this mechanism has not been proven scientifically, it seems logical. This type of leak is expected to be more common in an underinflated implant, which would allow more folds to develop. It is also expected to be more common in saline implants than in gel implants because the more viscous nature of the gel would 'cushion' folds in the shell $(5,9)$. In 1996, Tebbetts (10) provided further support for the fold flaw theory. It was shown that, in the body, all smooth-shell round saline implants fall to the bottom of the periprosthetic pocket, so that the upper pole of the implant is always collapsed and wrinkled, even if the implant is overfilled $15 \%$ past the manufacturer's recommended volume.

From 1963 through 1991, about 95\% of all implanted breast prostheses were filled with silicone gel rather than saline (11). However, since the moratorium on silicone gel breast implants (January 6, 1992), the use of inflatable saline 


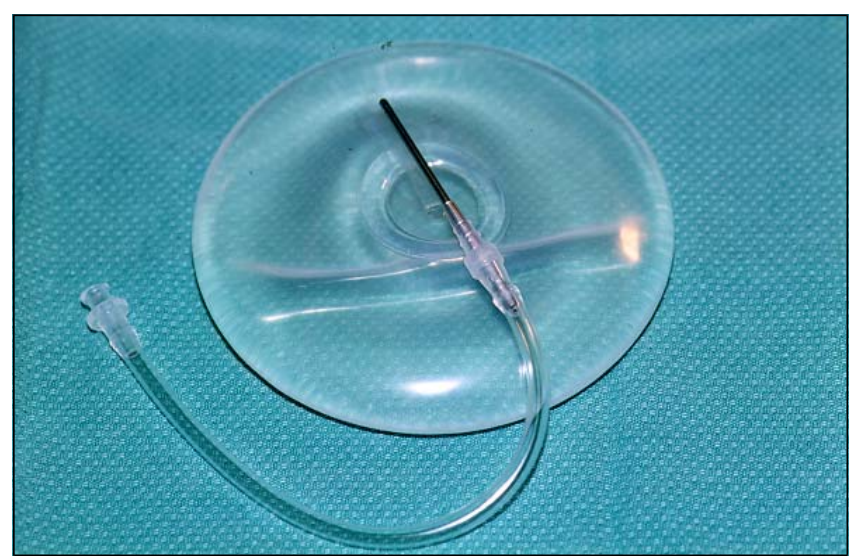

Figure 3) The Mentor Model 1800 leaf valve inflatable saline implant. Saline is injected by a metal catheter into the leaf valve mechanism

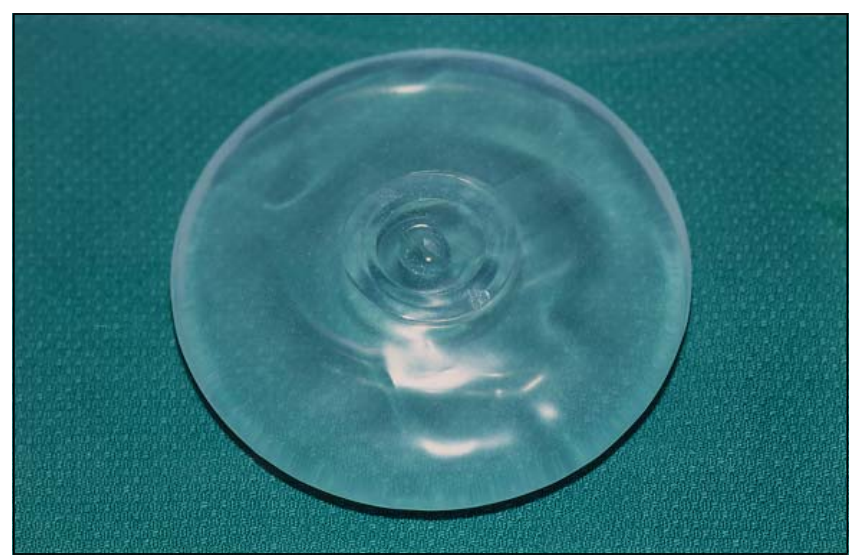

Figure 4) A refilled failed implant that was left on a flat surface overnight demonstrating a large drop of saline at the external site of the valve

implants has escalated. In Canada, most plastic surgeons use smooth-walled implants. Textured implants have only become freely available since May 1997 . The present study describes the mechanism of failure in one style of smoothwalled implant, the Mentor Model 1800 inflatable leaf valve implant (Mentor Corporation, Texas).

\section{RESULTS}

From 1992 to 1996, 189 Mentor Model 1800 saline breast implants were inserted into patients (54 for breast augmentation and 135 for replacement of explanted silicone gel implants). Nine of these implants (4.8\%) spontaneously deflated at a mean time of 2.8 months postoperatively (range 0.5 to 10 months) (Table 1). Six deflations were partial (10\% to $50 \%$ of implant volume) (Figure 1), and three were complete (Figure 2). The failure times of all nine implants are shown in Table 1. All failed implants were from the same manufacturer and had the same leaf valves (Mentor Model 1800) (Figure 3). This type of implant is filled by introducing a metal catheter into the leaf valve mechanism.

None of the failed implants demonstrated any visible defects in their walls or valve mechanisms when examined in the operating room. However, subsequent analyses demonstrated that if these failed implants were carefully refilled and

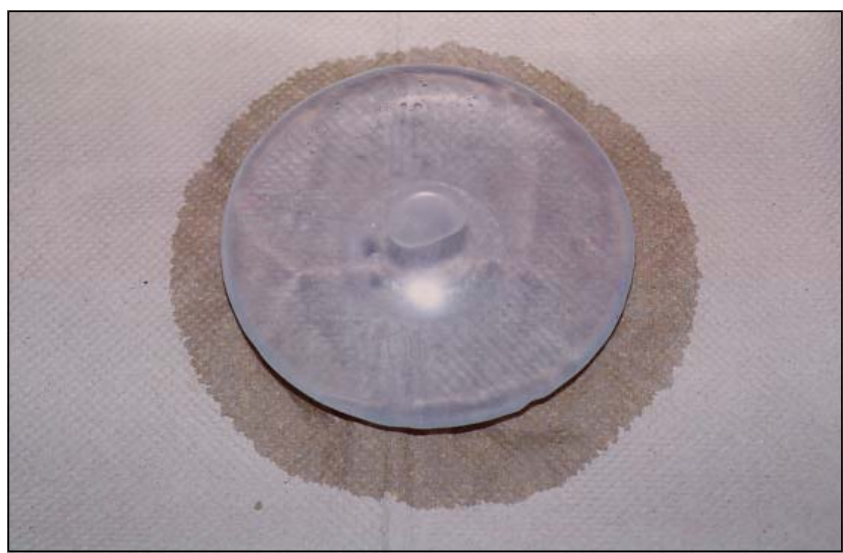

Figure 5) When the implant in Figure 4 was left on a paper towel, a large ring of saline formed around the implant after 6 to $8 \mathrm{~h}$

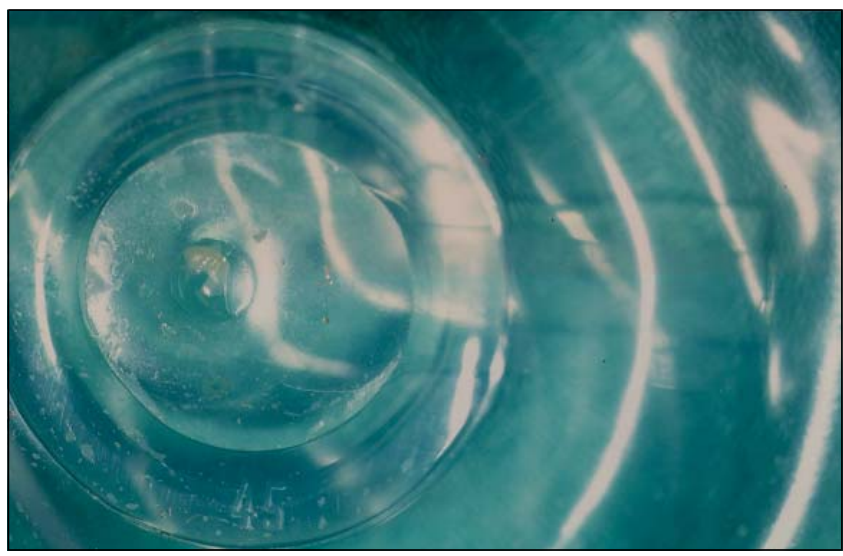

Figure 6) In three of the implants with delayed leakage (Table 1), fibrous tissue was observed in the valve mechanism. This may have served as a 'wick' to stimulate fluid leakage

left on a flat surface, they demonstrated a slow leak through the external leaf valve mechanism - as slow as two to three drops per $12 \mathrm{~h}$ (Figure 4). This rate increased when pressure was applied to the implants. When an implant was left on a paper towel, a large ring of saline formed around the implant over 6 to $8 \mathrm{~h}$ (Figure 5).

In three of the implants with delayed leakage (three to nine months, Table 1), fibrous tissue ingrowth was observed in the leaf valve mechanism of the deflated implants (Figure 6). It is postulated that failure in all nine implants resulted because of defects in their valves and that tissue ingrowth into the leaf catheter valve mechanism may have played a role in at least three of them. This tissue may have provided a 'wick' to stimulate fluid leakage.

Since May 1996, no further Mentor Model 1800 leaf valve implants have been used by the author. These implants have been replaced by the Mentor Model 1600 diaphragm valve implants (with plugs). No failures have been observed in any of the 68 diaphragm valve implants that have been inserted into patients during the past year.

While this study was being completed, eight similarly deflated Mentor 1800 leaf valve implants, which had been inserted by other surgeons, were removed by the author. Two of these implants were removed two years after insertion. 
TABLE 1: Failure properties of nine of 189 inflatable saline implants that leaked

\begin{tabular}{lccc}
\hline Implant & Time (months) & Deflation (\%) & Fibrous tissue \\
\hline 1 & 0.5 & 50 & No \\
2 & 0.5 & 40 & No \\
3 & 0.5 & 100 & No \\
4 & 1.0 & 10 & No \\
5 & 1.0 & 100 & No \\
6 & 1.0 & 20 & No \\
7 & 3.0 & 40 & Yes \\
8 & 6.0 & 30 & Yes \\
9 & 9.0 & 100 & Yes \\
\hline
\end{tabular}

In three implants (implants 7 to 9), fibrous tissue was demonstrated in the valve mechanism (Figure 6)

The patient related that both breasts had become progressively smaller over the two years. One implant was about half deflated; the other was completely deflated. When these $300 \mathrm{~mL}$ implants were injected to $285 \mathrm{~mL}$, there was no immediately observable leak in their shells. However, when pressure was applied manually, a drop of fluid formed on the external aspect of the valve over 5 to 10 mins. When these implants were left on a paper towel and weighed twice weekly, their weights progressively decreased with time (Figure 7). Over six weeks, one implant leaked 23\% of its volume, and the other leaked $71 \%$ of its volume (Figure 7).

\section{DISCUSSION}

Of 189 inflatable saline breast implants inserted into patients from 1992 to 1996, nine (4.8\%) spontaneously deflated at a mean time of 2.8 months postoperation (range 0.5 to 10 months). Six deflations were partial (10\% to $50 \%$ of the implant volume) and three were complete. There is little recent information on the leakage properties of modern saline inflatable implants. In 1996, Gibney (12) reported a three-year deflation rate of $0.7 \%$ in 150 Mentor Heyer-Schulte implants with the diaphragm valve design (with plugs). A research study by the American Society of Plastic Surgery is analyzing the failure rate in a large number of recently implanted saline implants from various manufacturers. The high $4.8 \%$ deflation rate in the present study appears to be related to one particular implant type - the Mentor Model 1800 leaflet valve design. Since these implants were discontinued and replaced with the Mentor Model 1600 diaphragm valve design implants, no deflations have been observed in 68 implants inserted during the past year.

Over the years, the concept of deflation of saline implants has been viewed as an all or nothing phenomenon - once there was a defect in the implant, there was complete or near complete deflation of the involved implant. The concept of

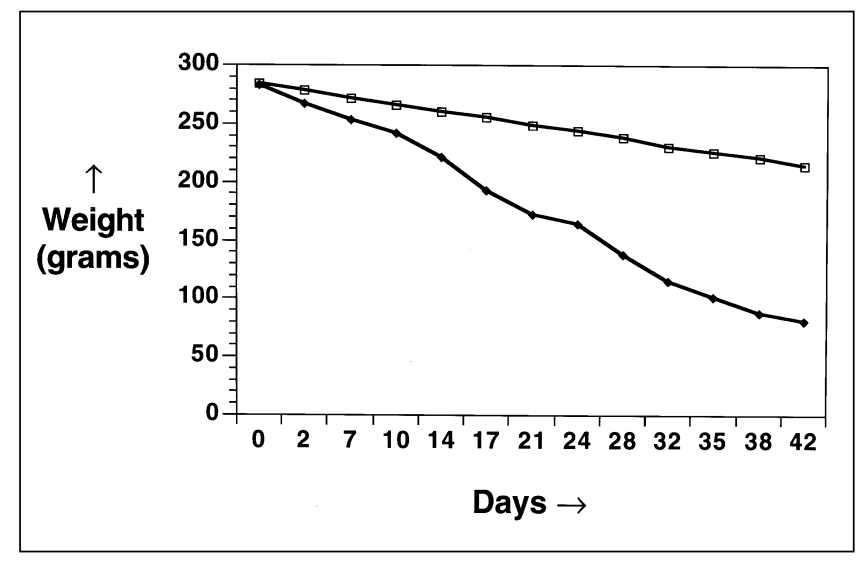

Figure 7) Deflation patterns of two saline implants that were removed from a patient two years after insertion, refilled and placed on a paper towel. The patient had complained of a slow reduction in breast volume over the two years. At two years, one implant was half deflated, and the other was completely deflated. After six weeks, one implant lost $71 \%$ of its volume (ם) and the other lost $23 \%$ (口)

partial deflation of a saline implant is relatively new. There has only been one report of this type of partial deflation in the literature (13). The patient in that study was a 26-year-old bodybuilder, who presented with a $50 \mathrm{~mL}$ loss in volume of a $270 \mathrm{~mL}$ McGhan Biocell (California) inflatable implant, which had been inserted eight months previously. No abnormality was noted in either the implant or the valve mechanism. The present study indicates that partial deflation is more common than was previously realized, at least in the Mentor Model 1800 implant.

The exact etiology of the deflation mechanism in this study has not been fully defined. However, failure of the valve mechanism was observed in all involved implants. This failure may have been due to pre-existing mechanical failure related to the initial construction of the implants. Alternatively, the valve mechanism may have been altered during inflation with the metal catheter. Although this injection was always done very carefully, the process could have altered the structure or function of the valve. In three implants with late deflations (three to nine months), fibrous tissue was observed in the valve mechanism of the implants (Figure 6). This tissue may have played a role by providing a 'wick' to stimulate saline leakage, possibly by capillary action similar to that seen when a faulty implant was placed on a paper towel.

Fibrous tissue ingrowth into the valve mechanism of other types of inflatable implants has been reported (14). In four of these McGhan implants (style 168 and style 468 textured saline implants), the plugs on the filling valves became unplugged, and the 'straps' of the plugs became embedded in the fibrous tissue of the anterior breast capsule. No leakage was found in any of those implants.

The implant leakage in this study appears to have been related to a specific type of implant - the Mentor Model 1800 leaflet valve implant. It should be pointed out that in all cases, the manufacturer provided a new replacement implant to the patient without charge. 


\section{REFERENCES}

1. Cronin TD, Gerow FG. Augmentation mammaplasty: A new 'natural feel' prosthesis. Transactions of the Third International Congress of Plastic Surgery. Amsterdam: Excerpta Medica Foundation, 1964:41-9.

2. Williams JE. Experiences with a large series of silastic breast implants. Plast Reconstr Surg 1972;49:253-70.

3. Tabari K. Augmentation mammaplasty with Simaplast implants. Plast Reconstr Surg 1969;44:468-70.

4. Regnault P, Baker TJ, Gleson MC, et al. Clinical trial and evaluation of a proposed new inflatable mammary prosthesis. Plast Reconstr Surg 1972;50:220-6.

5. McGrath MH, Burkhardt BR. The safety and efficacy of breast implants for augmentation mammaplasty. Plast Reconstr Surg 1984;74:550-60.

6. Grossman AR. The current status of augmentation mammaplasty. Plast Reconstr Surg 1973;52:1-7.

7. Hetter GP. Satisfactions and dissatisfactions of patients with augmentation mammaplasty. Plast Reconstr Surg 1979;64:151-5.
8. Trupman ES, Ellenby JD. A 13-year evaluation of sub-pectoral augmentation mammaplasty. In: Owsley JQ Jr, Peterson RA, eds. Symposium on Aesthetic Surgery of the Breast. St Louis: Mosby, 1978:344-52.

9. Worton EW, Seifert LN, Sherwood R. Late leakage of inflatable silicone breast prostheses. Plast Reconstr Surg 1980;65:302-6.

10. Tebbetts JB. What is adequate fill? Implications in breast implant surgery. Plast Reconstr Surg 1996:97:1451-4.

11. Peters WJ. The current status of silicone-gel breast implants. Can J Plast Surg 1994;2:18-23.

12. Gibney J. Saline breast implant deflation rate. Plast Reconstr Surg 1996;95:1329.

13. Cederna JP. Partial deflation of a saline breast implant. Plast Reconstr Surg 1996;97:684.

14. Umansky C. Plugs on the filling valves of saline breast implants. Plast Reconstr Surg 1996;98:914. 